\title{
Log-sequence analysis and environmental aspects of the Lower Jurassic Fjerritslev Formation in the Danish Subbasin
}

BY

OLAF MICHELSEN

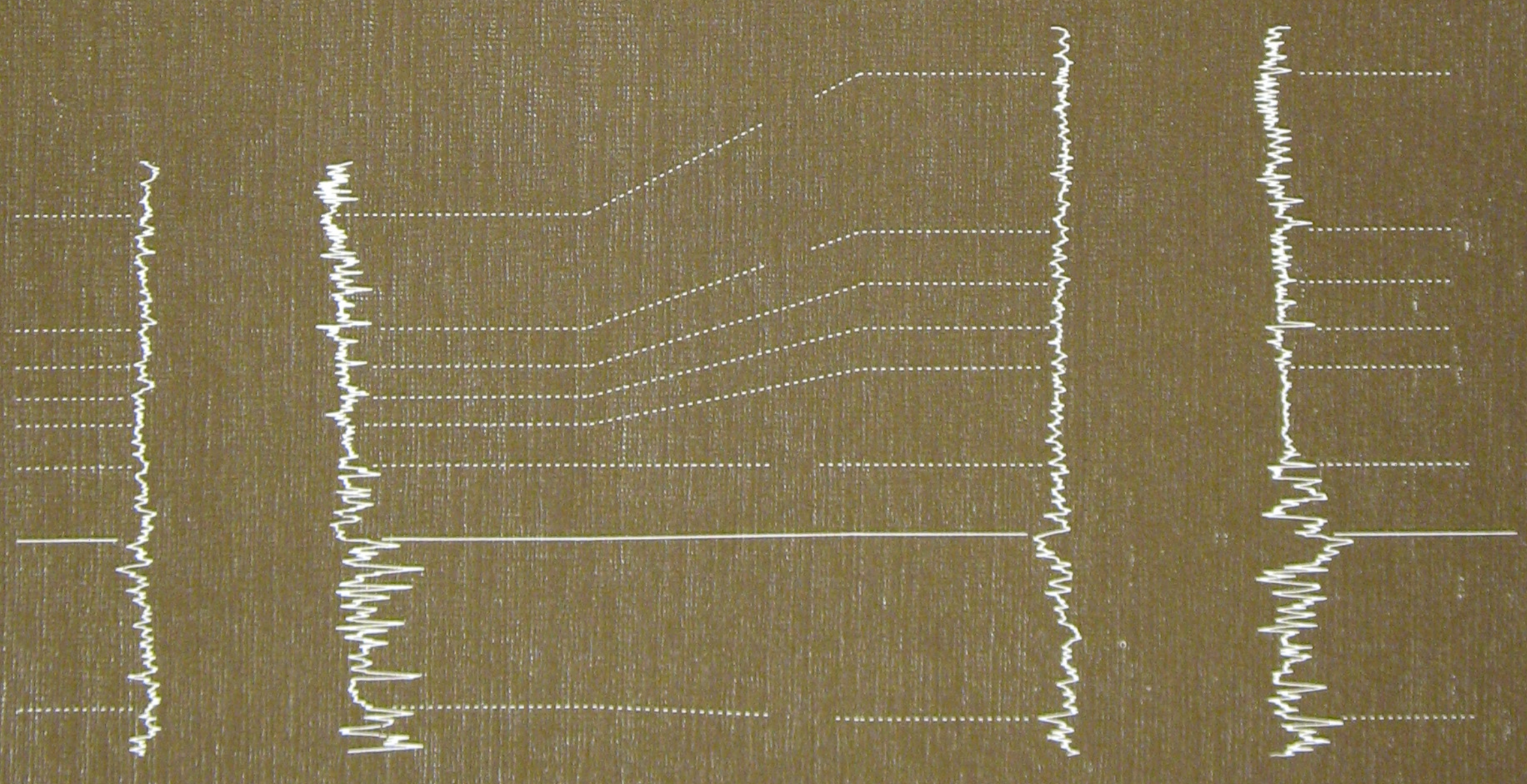




\section{Log-sequence analysis and environmental aspects of the Lower Jurassic Fjerritslev Formation in the Danish Subbasin}

BY

OLAF MICHELSEN

Danmarks Geologiske Undersøgelse · København 1989 
Key words:

Danish Subbasin, Lower Jurassic, Fjerritslev Formation, stratigraphy, log-sequences,

environmental conditions.

\section{Vignette:}

Detailed log-stratigraphic subdivision and correlation.

DGU Serie A nr. 25

ISBN 87-88640-44-2

ISSN 0901-0270

Oplag: 1000

Tryk: AiO Tryk as, Odense

Tegning: Eva Melskens

Dato: 9-10-1989

Olaf Michelsen,

DGU, Thoravej 8,

DK-2400 København NV

Redaktion: Leif Banke Rasmussen

(C) Danmarks Geologiske Undersøgelse

Thoravej 8, DK-2400 København NV

I kommission hos: Geografforlaget ApS

Ekspedition: Fruerhøjvej 43, 5464 Brenderup

Telefon: 64441683 


\section{Contents}

\begin{tabular}{|c|c|c|}
\hline Abstract $\ldots$. & 4 & Upper depositional sequence (F-III/F-IV \\
\hline Introduction $\ldots \ldots \ldots \ldots \ldots$ & 5 & members $), \ldots \ldots \ldots \ldots \ldots \ldots \ldots \ldots$ \\
\hline Biostratigraphic subdivision .. & 7 & Discussion and conclusions . \\
\hline Lithostratigraphic subdivision. & 8 & Environmental conditions .... \\
\hline Log-sequence analysis $\ldots \ldots \ldots \ldots \ldots \ldots \ldots$ & 10 & Organic geochemistry.. \\
\hline Minor log-sequences and strata boundaries.... & 10 & Benthonic faunas..... \\
\hline Lower depositional sequence (F-Ia/F-Ib & & Summary........... \\
\hline 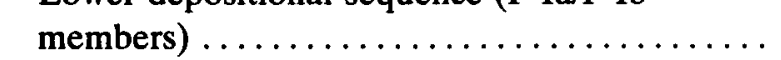 & 13 & Acknowledgments. . \\
\hline Middle depositional sequence (F-II member) .. & 14 & References ....... \\
\hline
\end{tabular}




\section{Abstract}

The lithostratigraphic, biostratigraphic, and chronostratigraphic subdivisions of the Lower Jurassic Fjerritslev Formation in the Danish Subbasin are discussed in relation to a log-sequence analysis. The formation is subdivided into three depositional sequences. The upper and lower sequences comprise 15 minor log-sequences, which can be correlated between most well sections. These minor log-sequences are separated by strata boundaries, which by means of biostratigraphic data are shown to be synchronous.
The depositional environment is discussed on the basis of previously published data and new organic geochemical data, and in relation to the published sealevel curve. Five major events of eustatic sea-level rises seem to have influenced the benthonic faunas; faunal diversity and density decreased during the sea-level rises, and subsequently increased during the higher sea-level stillstands. The level of oxygen in the bottom waters decreased during the Early Jurassic transgression. 


\section{Introduction}

The Lower Jurassic Fjerritslev Formation has been shown to include the most promising source rock for oil and gas generation in the Danish Subbasin (Thomsen et al. 1987). Consequently, detailed seismic mapping and well analyses have been carried out recently to support a basin modelling project concerning the hydrocarbon potential of the region. This paper represents detailed stratigraphic studies of the Fjerritslev Formation, based on log-sequence analysis correlated to biostratigraphy described in Michelsen (1975). A major goal of the study was to refine the level of chronostratigraphic correlation between well sections; recognition and correlation of log-motifs proved as efficient and reliable for subdividing and correlating the formation. The chronostratigraphic subdivision derives from the biostratigraphic data and was interpolated laterally and vertically by means of the log-correlation.

Core samples and cuttings samples are available for biostratigraphic studies. Core samples are only avail- able from some older wells and generally with a scattered occurrence in the sequence. A few macrofossils, e.g. ammonites, have been collected from the Lower Jurassic succession (Sorgenfrei \& Buch 1964, Michelsen 1975). Reference to certain ammonite zones is thus possible locally, but without determination of the zonal boundaries. Micropalaeontological and palynological studies based on core samples have led to the definition of faunal and floral assemblages, but not to the precise location of the zonal boundaries (Michelsen 1975, Dybkjær 1988).

More commonly, however, micropalaeontogical and palynological studies have to be carried out on cuttings, sampled at intervals of 10,20 , or $30 \mathrm{ft}$; ; representing the most complete record of the drilled sequences. However, although the cuttings sample is referred to a certain depth level, it comprises material from an undetermined thickness of the sequence, since caving often occurs during the drilling process. Furthermore,

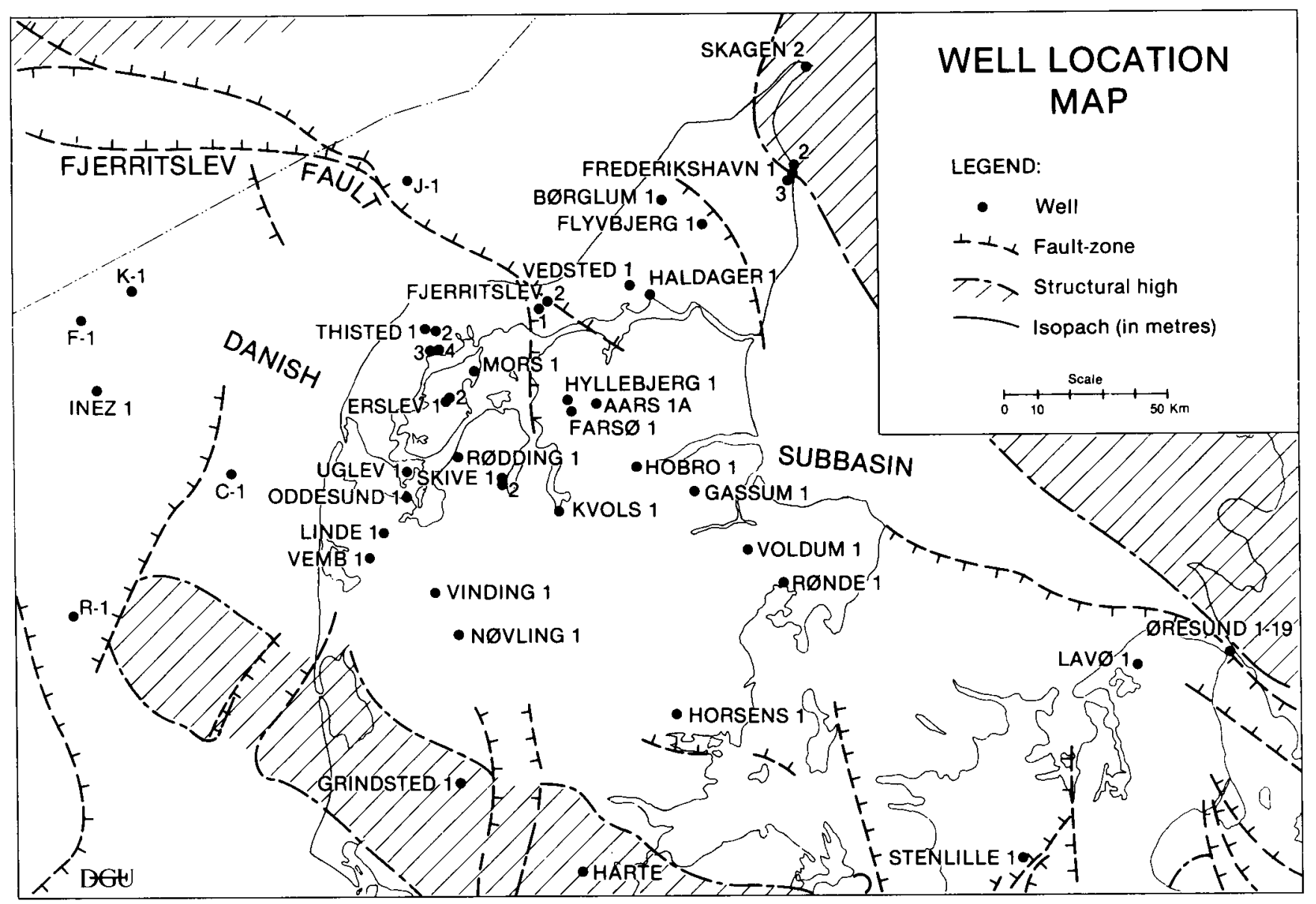

Fig. 1: Structural map of the Danish Subbasin with the well locations. 
drilling rate, hole conditions, and rate of mud circulation contribute to the uncertainty of the sample depth. Consequently, faunal and floral zones are defined by the uppermost occurrence of selected species in cuttings samples, since a first appearance (lowermost occurrence) may be blurred due to cavings. For the same reason the uppermost occurrence of low density faunas and floras may be recognized at too great a depth in the sequence. The biostratigraphical subdivision carried out in well sections is, therefore, not precise enough for determination and correlation of stage boundaries.

The lithostratigraphic subdivision of the Fjerritslev Formation, in the F-Ia to F-IV members, is based on lithology described from the available samples and on interpretation of the petrophysical measurements (logs). The formation and member boundaries are defined by significant log-markers (Michelsen 1978, in press). In contrast to the problems of accurately locating cuttings samples as described above, the log-readings represent a large number of closely spaced physical measurements at relatively precise depths.

Each of these five members has a characteristic succession of log-motifs which can be correlated between well sections over large distances. Detailed analyses of the log-motifs led to the identification of minor logsequences, which represent sedimentary sequences. Mitchum et al. (1977) and Rider (1986) discussed the use of log-motifs or log-sequences as representatives of sedimentary sequences, which are chronostratigraphically significant. The stratigraphic concept refers to that used in seismic sequence stratigraphy (Mitchum et al. 1977) and in sequence stratigraphy (Wheeler 1958, Hedberg 1976). This subject is discussed further in a subsequent section. 


\section{Biostratigraphic subdivision}

The Lower Jurassic biostratigraphic and chronostratigraphic zonation is based on analyses of the ostracod faunas (Michelsen 1975). The recently published analyses of the palynomorphs confirm this chronostratigraphic scheme (Dybkjær 1988). The chronostratigraphic validity of the ostracod zonation is discussed below with references to the earlier analysis of core samples from the Gassum-1 well (Michelsen 1975) and new detailed analysis of cuttings samples from the Hyllebjerg-1 well (p1.1). The latter well encountered a complete section through the Fjerritslev Formation (fig. 3).

The base of the Lower Jurassic (or of the Hettangian) is regarded as coinciding with the base of the Fjerritslev Formation in the central parts of the basin (Michelsen 1978). Recent palynological studies carried out by Dybkjær (1988) in the Gassum-1 well section indicate a Late Triassic age for the uppermost core in the Gassum Formation, immediately underlying the Fjerritslev Formation.

The Hettangian-Sinemurian boundary is difficult to determine with certainty on the basis of ostracod faunas from cuttings samples. In the Gassum-1 well the stage boundary is located between the two informal subzones of the $O$. aspinata Zone. The $O$. aspinata assemblage of the upper subzone has a high diversity and comprises the genus Nanacythere whereas the fauna of the lower subzone has a low diversity (cf. Michelsen 1975 and fig. 11).

The Lower-Upper Sinemurian boundary is determined from the boundary between the $C$. betzi $-C$. crassireticulata Zone and the overlying $O$. danica Zone (fig. 11). The first-mentioned zone is rather thin and characterized by a fauna with low diversity and low density, which may explain why it is often missing in the cuttings samples. If this zone is not recognized, the stage boundary is placed between the $O$. aspinata Zone and the $O$. danica Zone.

The Sinemurian-Pliensbachian boundary is conventionally placed at the base of the $G$. apostolescui $-K$. (K.) foveolata Subzone, which is the uppermost subzone of the $O$. danica Zone (see fig. 11). Working with the cuttings samples, however, the lower boundary of the subzone must be placed at the uppermost occurrence of the underlying ostracod fauna, which is very sparse (fig. 11). Therefore, this boundary may be located too low in the sequence, or is not recognized, e.g. in the Fjerritslev-2 well (fig. 4). According to new studies by Fischer et al. (1986), the Sinemurian-Pliensbachian boundary in North Germany is situated a little above the base of the G. apostolescui $-K$. (K.) foveolata Subzone. The ostracod species $K$. (K.) variabilis, which characterizes the ostracod fauna below the base of this subzone, is not found in the uppermost $E$. raricostatum ammonite Zone in North Germany. The ostracod species $P$. harpa and $K$. (K.) foveolata, which are characteristic of the aforementioned ostracod subzone, also occur below the Sinemurian-Pliensbachian boundary in North Germany (Fischer et al. 1986). The correct determination of this stage boundary in the Danish region may, therefore, be a little above the lower boundary of the $G$. apostolescui $-K$. (K.) foveolata Subzone.

The Lower-Upper Pliensbachian boundary is placed at the boundary between the $O$. danica Zone and the overlying $O$. adenticulata $-N$. (N.) simplex Zone, and the Pliensbachian-Toarcian boundary at the top of the latter zone (fig. 11). Palynological studies of the uppermost core in the Gassum-1 well indicate an age near the Pliensbachian-Toarcian boundary (Dybkjær 1988).

The uppermost part of the Fjerritslev Formation, above the $O$. adenticulata $-N$. (N.) simplex Zone, is by custom referred to the Toarcian. Generally, the sequence is barren of ostracods, except a few isolated specimens (Michelsen 1975, figs. 7 and 16). With exception of an impoverished fauna found in core samples from the Haldager-1 and Vedsted-1 wells, sparse faunas were obtained from cuttings samples. The few ostracod species found indicate a Toarcian age. In the Hobro-1 well, Finn Bertelsen found an assemblage of palynoforms indicating a Toarcian age (cf. the appendix and plate 6 in Michelsen 1979).

The Lower-Middle Jurassic boundary is placed at the junction between the Fjerritslev and Haldager Sand Formations (see Michelsen et al. 1984, Michelsen in press). 


\section{Lithostratigraphic subdivision}

The lower and upper boundaries of the Fjerritslev Formation delimit a sequence of genetically related strata (Michelsen 1975 and 1978, Pedersen 1986). The lower boundary, between the Gassum and Fjerritslev Formations, is regarded as synchronous in the central part of the Danish Subbasin, whereas the Fjerritslev Formation oversteps the Gassum Formation north of the Fjerritslev Fault, being diachronous in this marginal part of the basin (Michelsen 1975 and 1978, Bertelsen 1978). The upper boundary represents an erosional unconformity in the southern parts of the Danish Subbasin (Michelsen 1978).

The lithostratigraphy is based on core samples, cuttings samples, and petrophysical logs, but the lithostratigraphic boundaries are defined at significant changes in the petrophysical measurements. The correlation between the Lower Jurassic lithostratigraphic and the biostratigraphic subdivisions is discussed below.

The boundary between the F-Ia and F-Ib members is located just below the top of the $O$. aspinata Zone (figs. 3, 4, and 11). The member boundary occurs in the uppermost part of this ostracod zone in the Hyllebjerg-1, Aars-1, Nøvling-1, and Rønde-1 wells, all of which have yielded high density ostracod faunas. In the Fjerritslev-2 well the top of the $O$. aspinata Zone is found beneath the member boundary, which may be due to poor sample quality in this older well. The conclusion is that this member boundary is located within the Lower Sinemurian and that it may be synchronous. Furthermore, it is suggested that the boundary is time-equivalent with the youngest intercalation of the Gassum Formation into the Fjerritslev Formation in the Vedsted-1 well (Michelsen 1978). The succession of log-motifs adjacent to the boundary, can be correlated between most well sections south of the Vedsted-1 well, indicating continuous sedimentation throughout this area during the Early Sinemurian.

The F-Ib/F-II member boundary is located within the $G$. apostolescui $-K$. (K.) foveolata Subzone in all well sections where the lower boundary of this subzone is recognized (figs. 3, 4 and 11). The boundary between these members thus occurs within the Lower Pliensbachian sequence.

The F-II/F-III member boundary is located in the lower part of the $O$. adenticulata - $N$. (N.) simplex Zone and, therefore, lies within the Upper Pliensbachian sequence (figs. 3, 4, 8, and 11).
The F-II member in the Fjerritslev-2 and Hyllebjerg-1 wells can be readily divided into three parts on the basis of log-motifs. Some of these log-motifs are easily recognized in other well sections (e.g. Rødding-1), but are unrecognized in some wells (e.g. Kvols- 1 and Rønde-1), - see figs. 3 and 4. Furthermore, the thickness of this member varies significantly, in comparison to the thickness variation within the other members. This variation in thickness and logcharacteristics is assumed to be the result of non-deposition or erosion, creating hiati in the lower and upper levels of the member. The presence of hiati, however, has not been substantiated by other methods; the resolution of the biostratigraphic and seismic stratigraphy data is not sufficiently detailed to recognize such minor diastems.

The log-motifs above and below the F-II member can be correlated between the well sections, indicating that the upper F-Ib member and lower F-III member do not include significant stratigraphic breaks.

The boundary between the F-III and F-IV members is located within that part of the sequence that is barren of ostracods and, therefore, within the inferred Toarcian part of the sequence. The succession of log-motifs adjacent to this member boundary can be correlated between the wells in the northern and central parts of the basin (figs. 4 and 8 ).

In the central part of the Danish Subbasin, the member boundaries appear to be approximately synchronous. Nearer the margins of the basin, north of the Fjerritslev Fault, hiati are known to occur, e.g. in Frederikshavn-2 (Michelsen 1975, pp. 45-46). The suggestion of diachronous relationships in the basin marginal area (Pedersen 1986, fig. 7) was based on biostratigraphic data derived from poor quality cuttings samples from older wells. The cuttings samples described by Michelsen (1975), yielded only sparse ostracod faunas. As mentioned previously, the ostracod zones are defined by the uppermost occurrence, and the cuttings samples often contain cavings from the overlying sequence. The upper boundary of a zone, therefore, may be located too deep in the well section. Some of the boundaries of the Fjerritslev Formation members in the Børglum-1, Flyvbjerg-1, and Vedsted-1 well sections, may, therefore, have been assigned too young ages by Pedersen (1986, fig. 7).

In the Frederikshavn-2 well section the boundary 
between the F-II and F-III members occurs within a continuously cored sequence. The boundary between the $G$. apostolescui. - K. (K.) faveolata Subzone and the $O$. adenticulata $-N$. (N.) simplex Zone is placed above this member boundary, suggesting that the latter is diachronous. Only the upper part of the $O$. adenticulata $-N$. (N.) simplex Zone is present, indicating the presence of a hiatus near the base of the F-III member; this may represent a period of non-deposition, probably corresponding to the lower ammonite zone of the Upper Pliensbachian. The occurrence of the index fossils of the G. apostolescui - K. (K.) foveolata Subzone in the F-III member, therefore, may be explained by reworking during a renewed transgression of the basin margin, resulting from the Late Pliensbachian sea level rise.

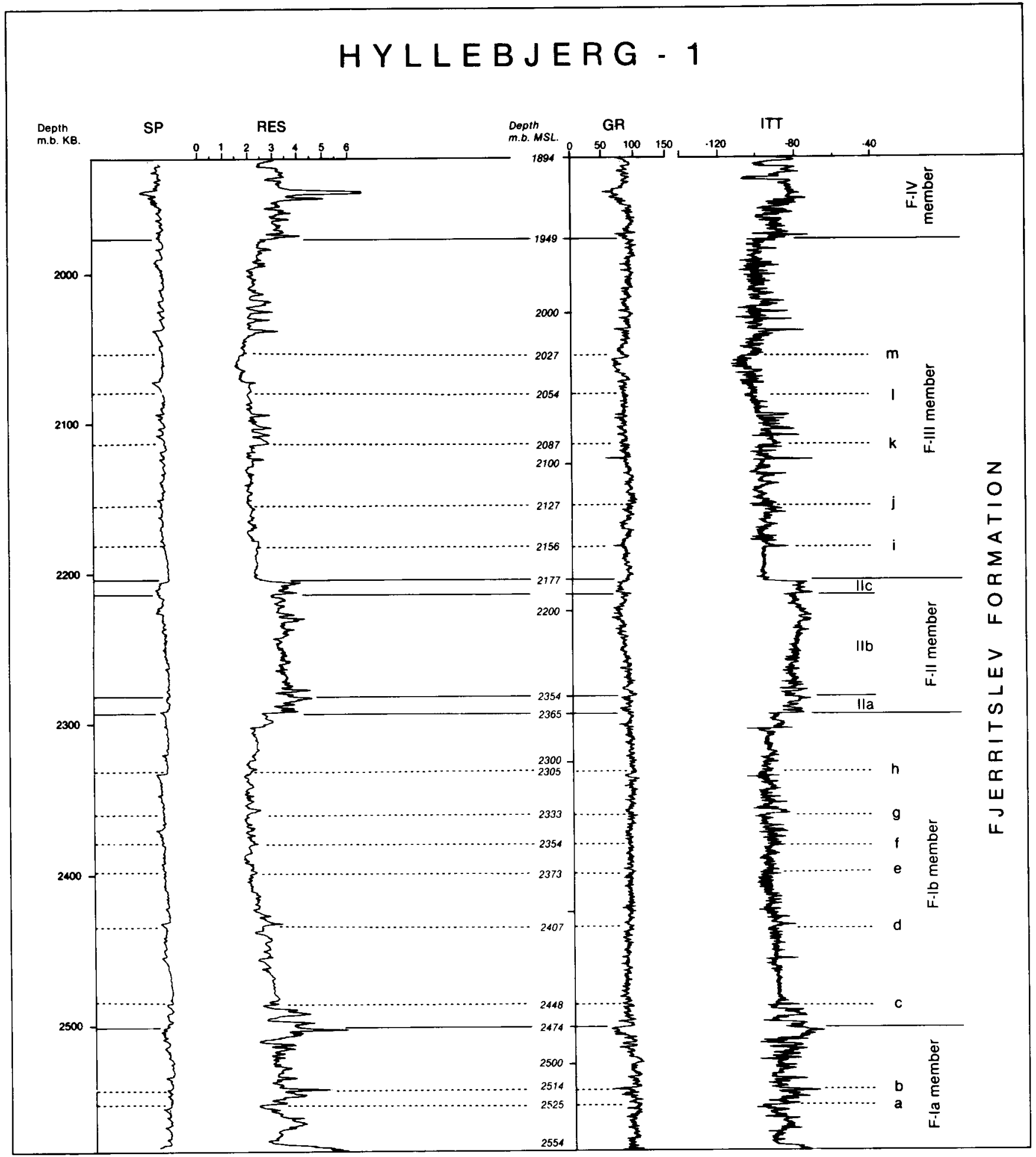

Fig. 2: The Fjerritslev Formation in the Hyllebjerg-1 well represented by the SP, Resistivity, Gamma Ray, and Interval Transit Time (»Sonic") logs. This well section is the reference section for the lithostratigraphic and the log-sequence subdivision of the formation. 


\section{Log-sequence analysis}

The concept of log-sequence stratigraphy refers to that described for the seismic sequence stratigraphy. According to the concept described by Mitchum et al. (1977) a depositional sequence is »a stratigraphic unit composed of a relatively conformable succession of genetically related strata and bounded at its top and base by unconformities or their correlative conformities«. It is, furthermore, regarded as a predictable succession of rocks deposited during a regional cycle of relative change of sea-level. Though the unconformity comprises a hiatus, Mitchum et al. (1977) regard it as chronostratigraphically significant because, in general, "rocks above an unconformity are everywhere younger than those below it«. Furthermore, strata boundaries separating strata or beds within the sequence are synchronous. The sequence surfaces at boundaries consisting of unconformities are not isochronous, but they bound a group of strata, each one deposited during the interval of time defined by the ages of the strata boundaries. Thus, the depositional sequence has a chronostratigraphic significance. Since the lithostratigraphic units are defined by the lithofacies, they may be diachronous and cross the strata boundaries.

\section{Minor log-sequences and strata boundaries}

The Lower Jurassic Fjerritslev Formation has been subdivided into five members. The lithostratigraphic discussion shows that the formation may be subdivided into three depositional sequences, in the sense of
Mitchum et al. (1977). The lower sequence includes the F-Ia and F-Ib members, the middle sequence the F-II member, and the upper one the F-III and F-IV members. The three depositional sequences are locally separated by unconformities (see the lithostratigraphic section).

Detailed analysis of petrophysical logs has led to the further subdivision of the Fjerritslev Formation into a number of minor log-sequences, which are recognized in most well sections. These minor log-sequences are defined in the Hyllebjerg-1 well (fig. 2). They are identified by log-motifs on the gamma ray (GR) and interval transit time (ITT) logs, the latter of which is the most useful in this clay-dominated formation. The SP and resistivity (RES) logs are included in fig. 2 to facilitate correlation with the older well sections. The minor log-sequences are separated by strata boundaries which are "numbered " by the letters "a 2). Recognition of these strata boundaries is essential to the log-sequence stratigraphy. The chronostratigraphic significance of the strata boundaries is indicated by biostratigraphic data, which is in accordance with the concept described by Mitchum et al. (1977).

The F-Ia/F-Ib and F-III/F-IV boundaries are not included in the log-analysis, though they appear chronostratigraphically significant. These member boundaries separate different lithologies, and they were identified by significant changes in the log-readings. In contrast, lithologic changes across the strata boundaries are not recognizable on basis of the petrophysical logs. 


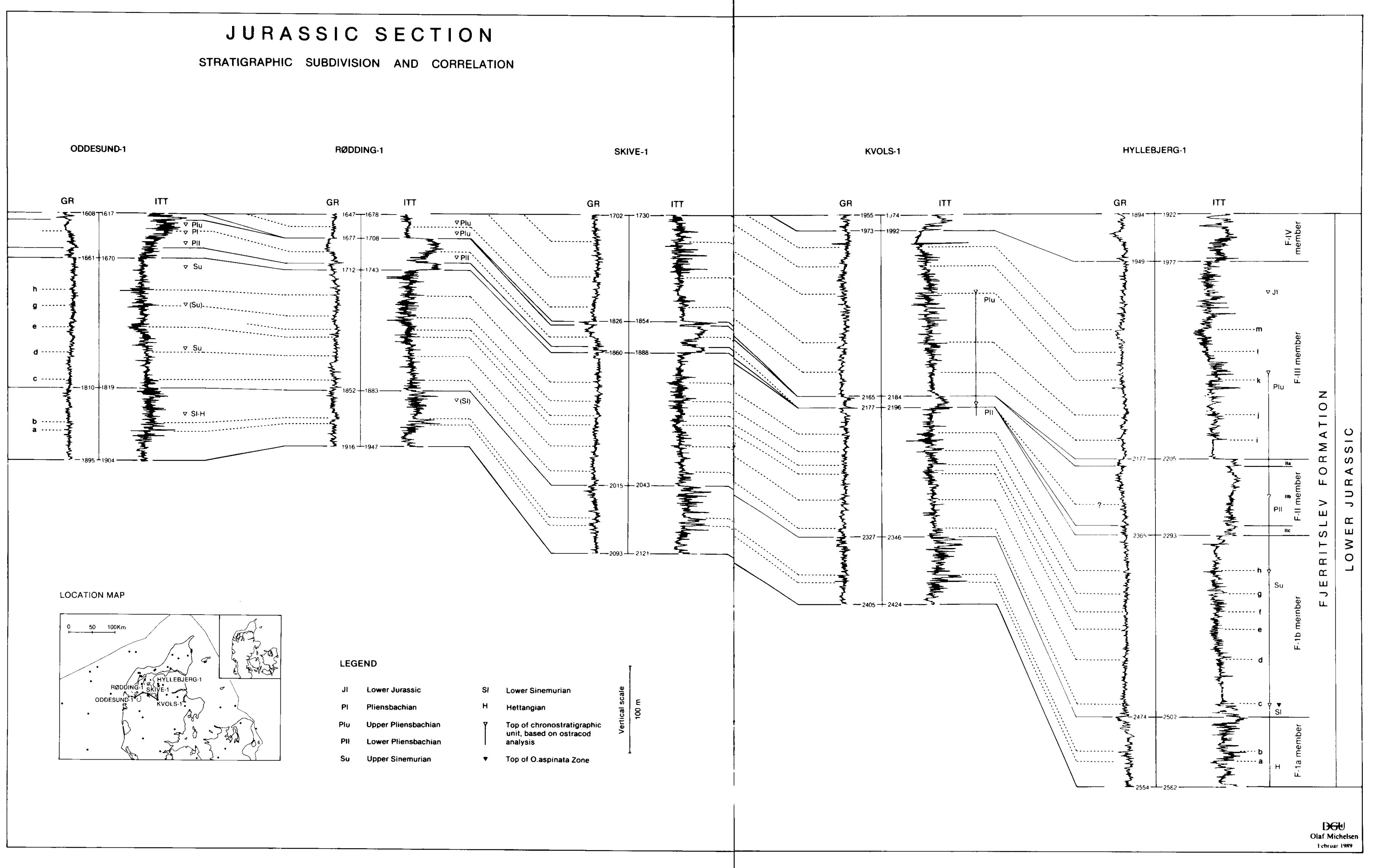

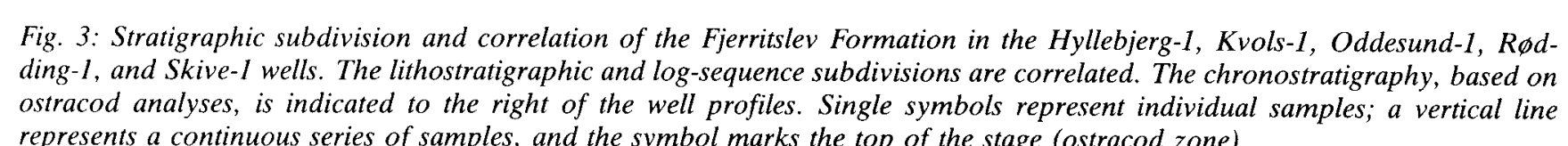




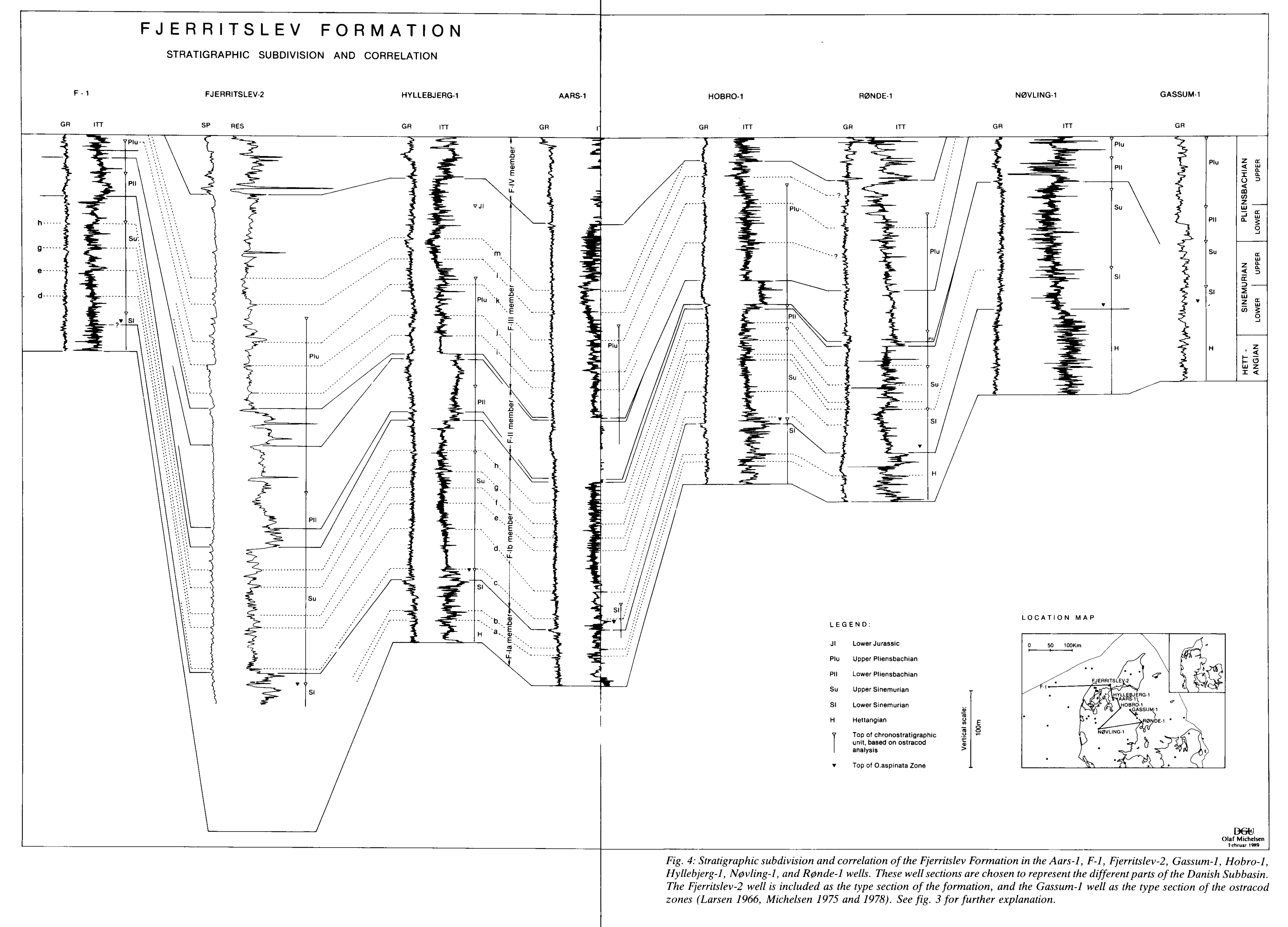




\section{The lower depositional sequence (F-Ia/F-Ib members)}

Nine minor log-sequences are identified, separated by the strata boundaries a to $h$. The lowermost three logsequences are characterized by marked deflections of the log-curves. The log-motifs are easily recognized in all well sections, with the exception of F-1, Rønde-1, and Nøvling-1. In the other well sections the log-motifs are identical though the thicknesses of individual logsequences may vary (figs. 3 and 4).

The upper six log-sequences are characterized by less nervous log-curves, which for each of the log-sequences show a characteristic pattern or motif. The sequences can clearly be identified in all well sections, with the exception of Nøvling-1 (figs. 3 and 4). The log-motifs and the thicknesses of the log-sequences show only small variations. The lower part of the log-sequence between $c$ and $d$ in the Hyllebjerg-1 well is characterized by very smooth curves (fig. 3), as also observed in the Fjerritslev-2 well (fig. 4). Detailed correlation with other wells, e.g. Skive-1 and Kvols-1, indicates that this lower, smooth part of the log-sequence between $\mathrm{c}$ and $\mathrm{d}$ is strongly condensed (figs. 3 and 5).

The strata boundary $\mathrm{c}$ is situated very close to the top of the $O$. aspinata Zone, which is the inferred top of the Lower Sinemurian in most well sections (figs. 3 and 4). According to Michelsen (1975), however, the Lower Sinemurian include the overlying $C$. betz $i-C$. crassireticulata Zone in the Gassum-1 well. As mentioned previously, the latter zone is characterized by a low density fauna and it is represented by a thin sequence. The biostratigraphy of the F-1, Rønde-1, and Nøvling-1 wells indicates that the $C$. betzi $-C$. crassireticulata Zone occurs above the strata boundary c, and demonstrates that the zone may vary significantly in thickness. As the fauna is sparse and the index fossil is also known from the lower part of the Upper Sinemurian, the recognition of this ostracod zone is not considered to be chronostratigraphically valid (Michelsen 1975, pp. 2728 ). Thus, until further stratigraphic data are available, the strata boundary $\mathrm{c}$ is considered to represent the top of the Lower Sinemurian.

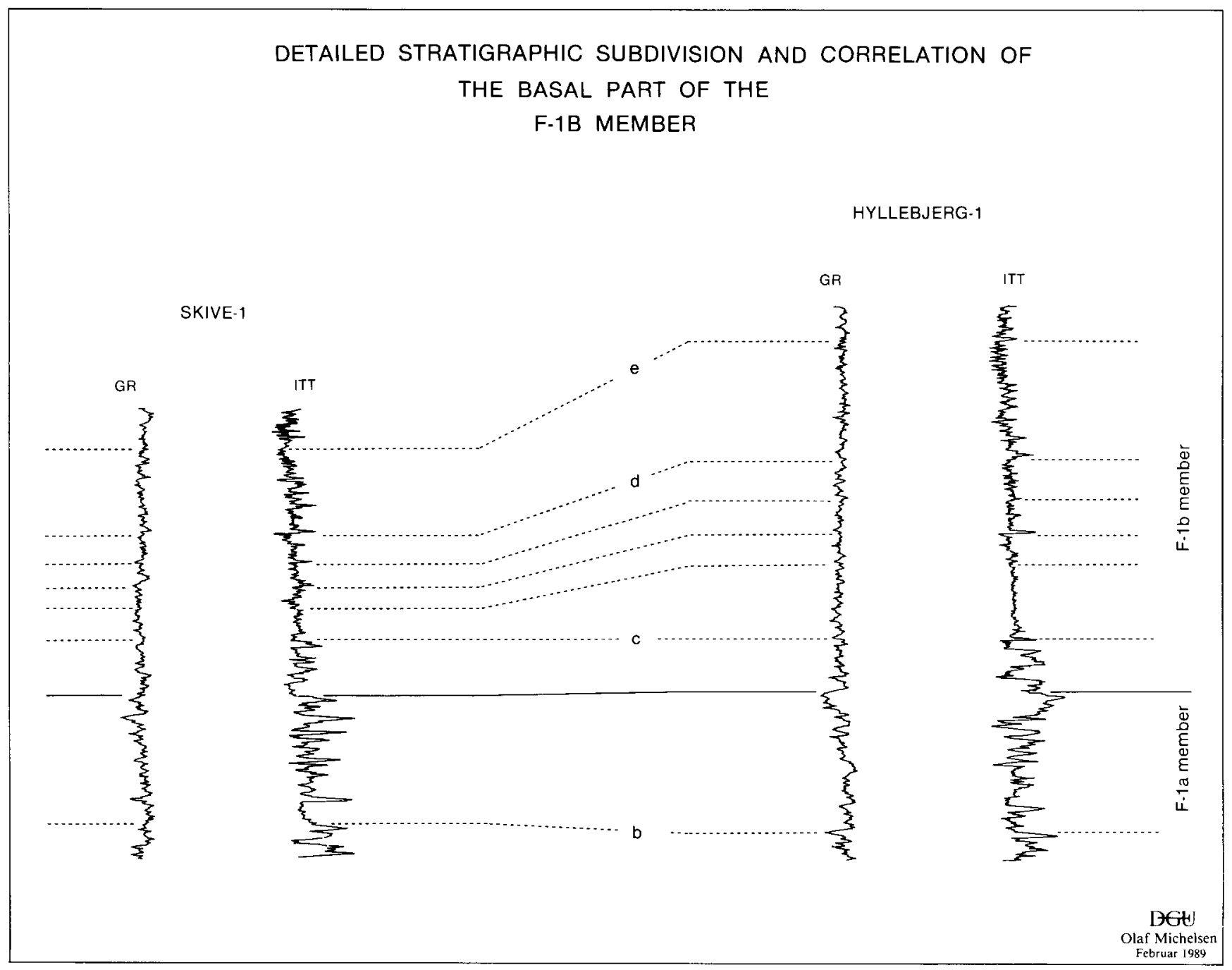

Fig. 5: Detailed stratigraphic subdivision and correlation of the basal part of the F-Ib member in the Hyllebjerg-1 and Skive-I wells. The data illustrate that a further subdivision of the minor log-sequences is correlatable, and that the lower part of the log-sequence between strata boundaries $c$ and $d$ is clearly condensed in the Skive-1 well section. For legend and well location see fig. 3 . 


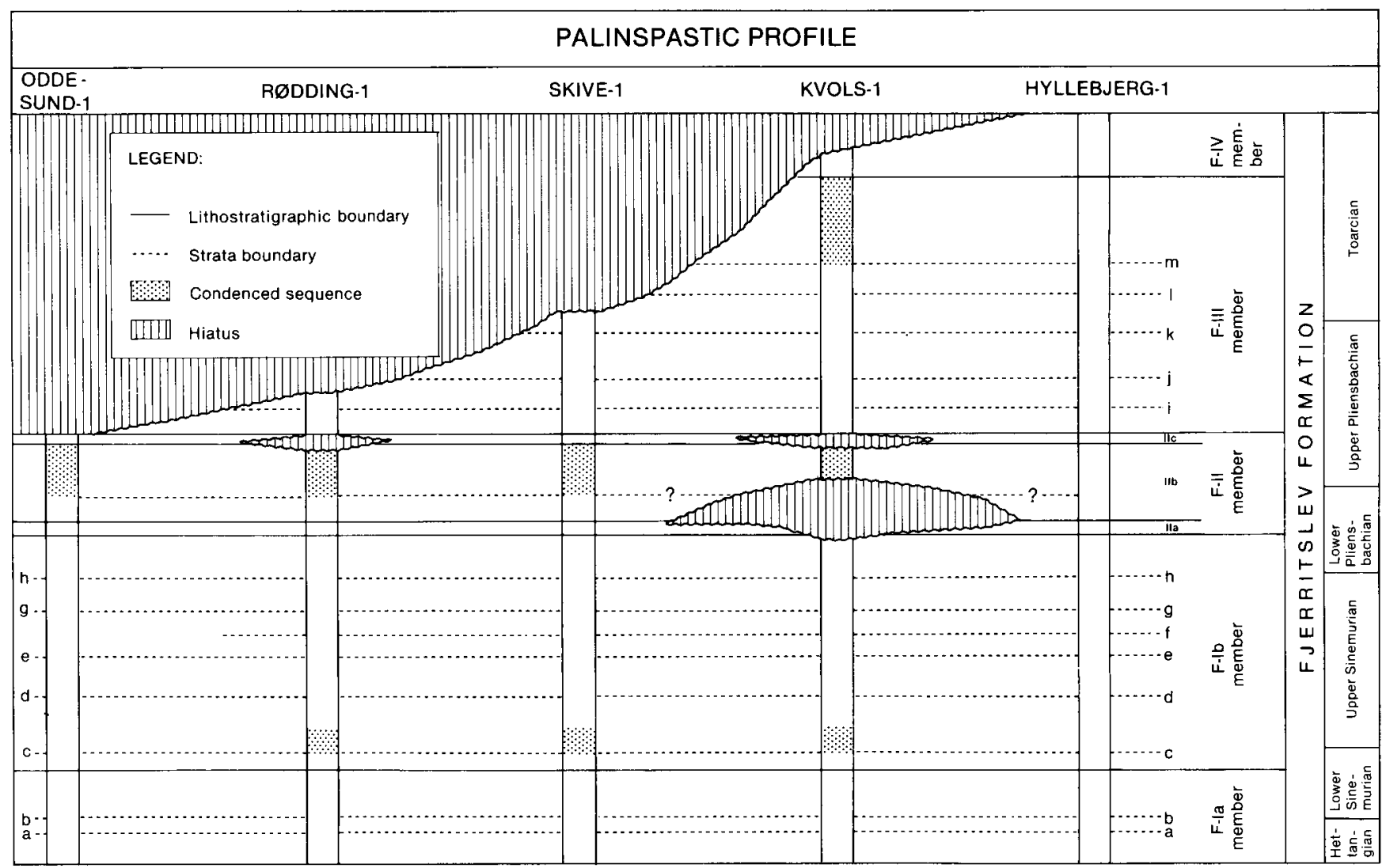

Fig. 6: A palinspastic interpretation of the data presented in fig. 3. The intervals between the strata boundaries are related to the depth intervals in the Hyllebjerg-I well, i.e. the vertical scale is not related to time intervals. The interpreted positions of hiati and condensed sequences are indicated.

The strata boundary $b$ is situated close to a level that shows weak biostratigraphic evidence of the Hettangian/Sinemurian boundary in a few well sections. In the Gassum-1 well this stage boundary is located between the subzones of the $O$. aspinata Zone. As mentioned above it is difficult to determine the position of this chronostratigraphic boundary from ostracod faunas, especially when derived from cuttings samples.

In the Oddesund-1 well the top of the Upper Sinemurian occurs in the middle of the log-sequence above strata boundary $h$. In all other well sections it is found immediately beneath this boundary. As mentioned above, the top of the Sinemurian is identified on the basis of a low density ostracod fauna. It is reasonable to suggest, therefore, that the strata boundary $h$ is situated within the uppermost part of Upper Sinemurian (close to the upper boundary).

\section{The middle depositional sequence ( $F-I I$ member)}

The F-II member has not been definitely subdivided into minor log-sequences due to the aforementioned variation in thickness and log characters. However, the original tripartite subdivision of the member is used to investigate the possible presence of hiati. These three parts of the member may be log-sequences in the sense used above and, furthermore, the middle part may be subdivided into two as indicated in fig. 3 . The data available permit the conclusion that the absence of the tripartite subdivision and the variation in thickness may indicate that local hiati are present in the uppermost and lowermost levels of this member (figs. 6 and 7).

\section{The upper depositional sequence (F-III/F-IV members)}

Six sequences are identified, separated by the strata boundaries $\mathrm{i}$ to $\mathrm{m}$. They are readily recognized in well sections (figs. 3 and 4), and only the log-sequence above boundary $\mathrm{m}$ varies significantly in thickness. This upper log-sequence comprises the uppermost part of the F-III member (above boundary $m$ ) and the F-IV member. These two members are identified in most well sections, where the Fjerritslev Formation is complete. The sequence above $\mathbf{m}$, in the F-III member, is apparently missing in the Hobro-1 and Rønde-1 well sections (fig. 4), whereas in the Kvols-1 well the same interval is present but thin and probably condensed (fig. 3). Due to the lack of biostratigraphic data and to the insignificant lithostratigraphic characteristics it cannot be concluded whether there is a hiatus uppermost 


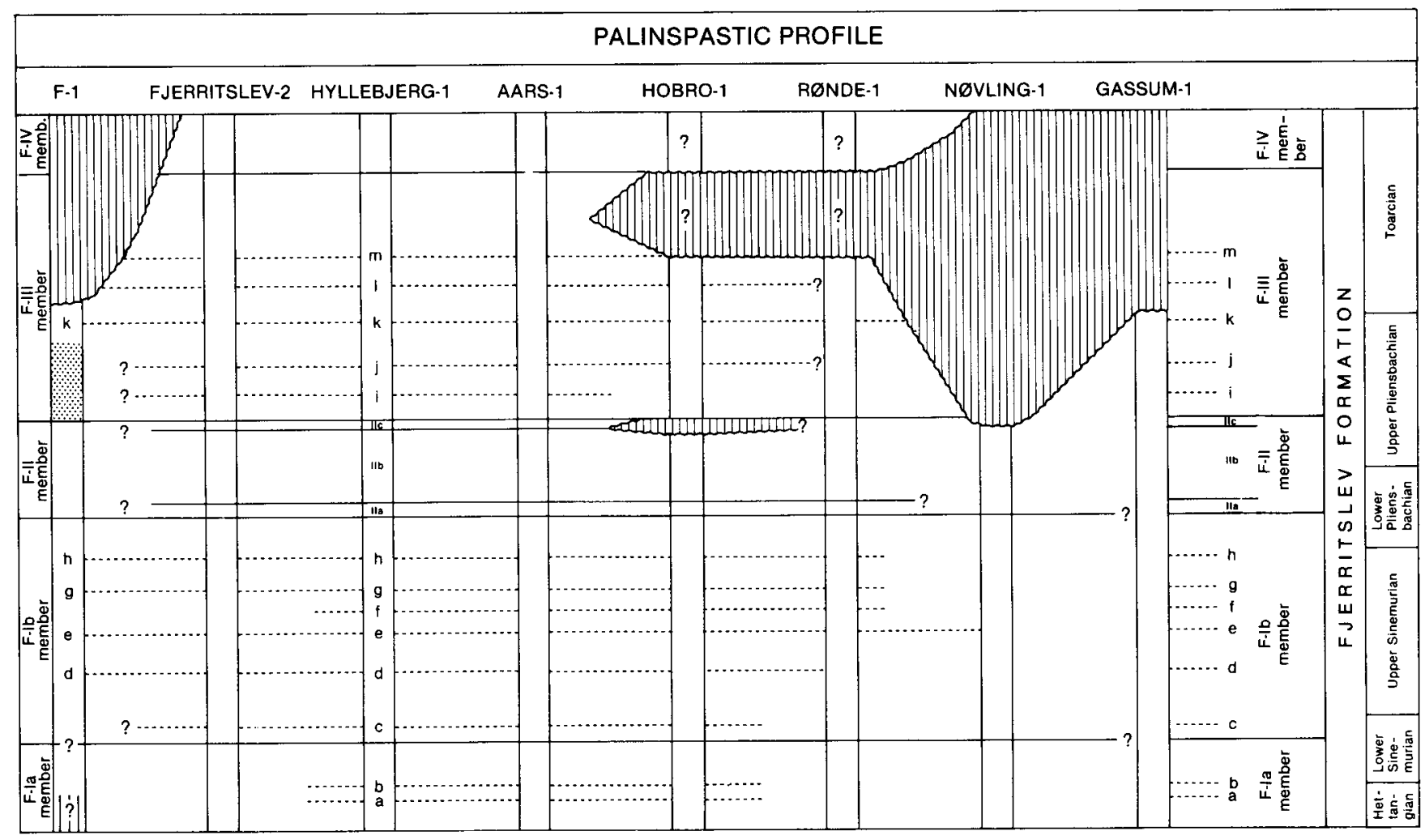

Fig. 7: A palinspastic interpretation of the data presented in fig. 4. The intervals between the strata boundaries are related to the depth intervals in the Hyllebjerg-1 well, i.e. the vertical scale is not related to time intervals. The interpreted positions of hiati and condensed sequences are indicated.

Note that the uppermost section in the Hobro-1 and Rønde-1 wells, which earlier had been assigned to the F-IV member, is difficult to correlate by means of log-motifs. It may equally correlate with the uppermost part of the F-III member. The presence of the hiatus indicated is, therefore, questionable. For legend see fig. 6.

in the F-III member in the Hobro-1 and Rønde-1 wells, or whether the F-IV member may be missing in these wells (figs. 4 and 7 ).

The strata boundaries $\mathrm{k}$ and $\mathrm{m}$ can be identified in and correlated between the Børglum- 1 and Frederikshavn-2 wells in the marginal part of the basin (fig. 8). In the Børglum-1 well the boundary $m$ corresponds to the base of F-IV member. As indicated in fig. 8, the lower boundary of the F-IV member may previously have been erroneously placed; the old, poor quality log-data often does not allow accurate identification of the lithological boundaries.

Boundary $\mathrm{k}$ is located at the base of a significant log-deflection, which becomes stronger in the more marginal parts of the basin (fig. 8). This log-motif has been discussed previously in relation to the biostratigraphy, since it always occurs in the upper part of the $O$. adenticulata $-N$. (N.) simplex ostracod Zone, which is indicative of a Late Pliensbachian age (Michelsen 1975). The top of this ostracod zone is recognized in all well sections within the log-sequence delimited by the strata boundaries $\mathrm{k}$ and 1 .

\section{Discussion and conclusions}

The detailed log-sequence analysis of the Fjerritslev Formation has demonstrated that it is possible to iden- tify minor log-sequences and to correlate them between well sections (figs. 3 and 4). The minor log-sequences are separated by strata boundaries that represent strata surfaces in the sense described by Mitchum et al. (1977).

Although the log-sequences are well-defined, the changes of the lithological character across the strata boundaries are not recognizable from the petrophysical logs. Thus, the lithological character of the log-sequences is clearly at an inferior level to that of lithostratigraphic units. The lithostratigraphic scheme is created on the basis of the recognition of sedimentary bodies consisting of sandstone, claystone etc. In contrast, it is assumed that the log-sequence stratigraphy can only be established in pelagic sediments. Correlation of the log-sequences or the strata boundaries is not possible across major litho-facies boundaries, as seems possible by the seismic sequence stratigraphy. Similarly, truncations, onlaps, downlaps etc. must be constructed in the log-sequence analysis, whereas these features can be recognized in the seismic stratigraphy.

The strata boundaries separating the minor log-sequences are synchronous, as indicated by the biostratigraphy. The minor changes in lithology represented by the small changes in the sonic velocities are probably related to variations in the environmental conditions on a regional scale. 


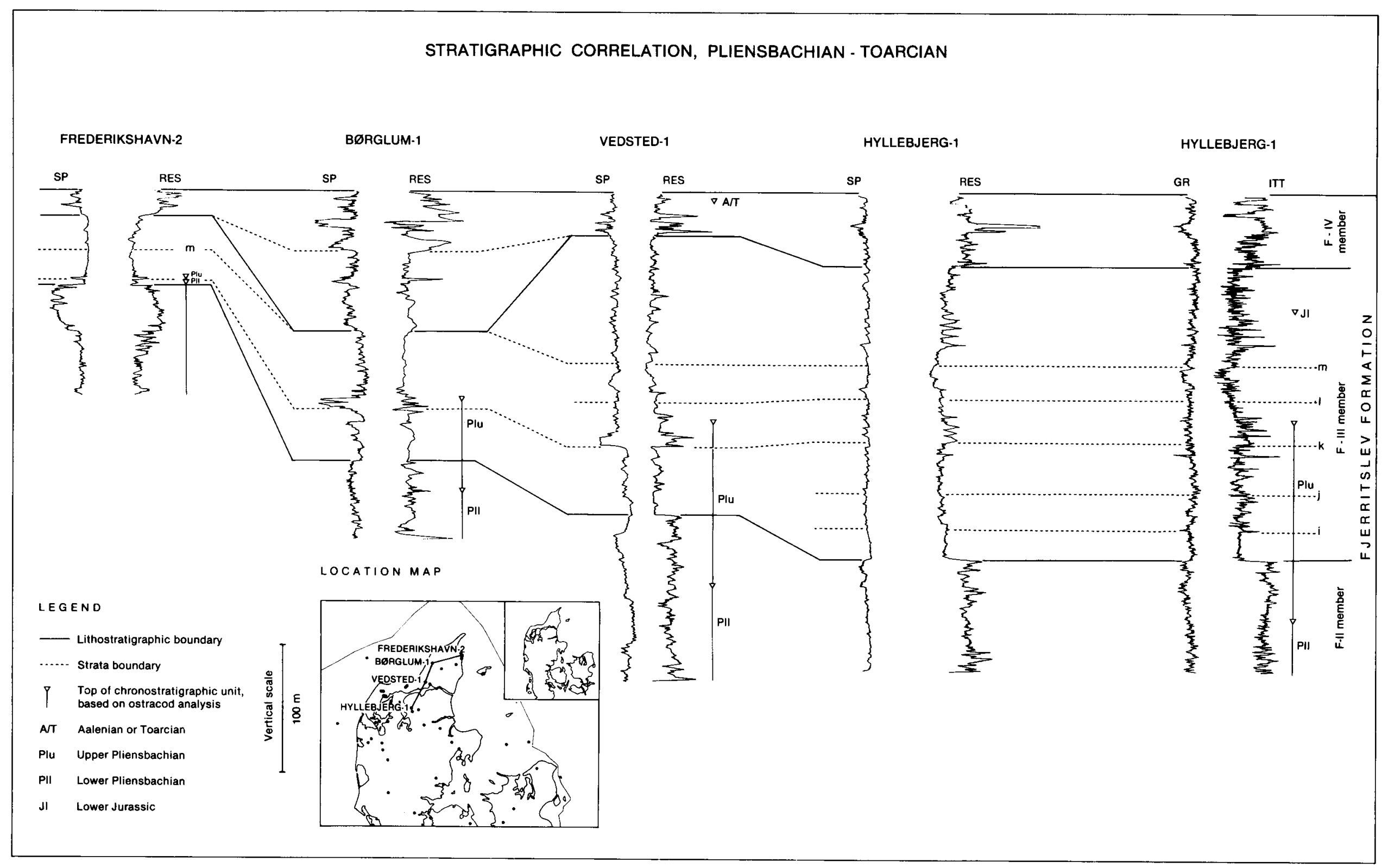


Biostratigraphy is necessary to document the chronostratigraphic significance of the strata boundary and to correlate the log-sequence stratigraphy to the chronostratigraphic subdivision. The log-sequence stratigraphy has a greater resolution than the biostratigraphy and it can subdivide stages into smaller units (fig. 11). Furthermore, individual log-sequences may themselves be subdivided into smaller units within a restricted geographic area (fig. 5).

The minor log-sequences are identified by means of the interval transit time log and may, therefore, be correlated with the seismic data, refining the seismic sequence stratigraphy and establishing cross-sections of the basin. In this respect and as a basis for constructing palinspastic profiles (figs. 6 and 7), log-sequence stratigraphy represents an important method in basin analysis and in quantitative basin modelling.

The combined study of the log-sequence stratigraphy and the biostratigraphy of the Fjerritslev Formation has created a framework that permits the determination of the position of the stage boundaries within the formation in the absence of biostratigraphic data. To this end, the following strata boundaries can be used:

Fig. 8: Stratigraphic correlation of the upper Fjerritslev Formation in the Børglum-1, Frederikshavn-2, Hyllebjerg-1, and Vedsted-1 wells, representing the central and marginal parts of the Danish Subbasin. Hyllebjerg-1 is represented by the SP, Resistivity, Gamma Ray, and Interval Transit Time logs to facilitate correlation with older wells. See fig. 3 for further explanation.
1) The Hettangian-Sinemurian boundary occurs close to the strata boundary $b$. The biostratigraphic data derived from cuttings samples at this level are not significant.

2) The Lower-Upper Sinemurian boundary is located immediately above the strata boundary c. The stage boundary corresponds to the top of the $O$. aspinata ostracod Zone, which is easily recognized.

3) The Sinemurian-Pliensbachian boundary is situated above the strata boundary h, but within the F-Ib member. The biostratigraphic evidence derived from cuttings samples is equivocal.

4) Biostratigraphic data accurately locate the LowerUpper Pliensbachian boundary within the F-II member (Michelsen 1975 and 1978). Distinct logmarkers are absent at this level.

5) The Pliensbachian-Toarcian boundary is located between the strata boundaries $\mathrm{k}$ and 1 . The biostratigraphic evidence of the Upper Pliensbachian is significant, but the data within the Toarcian stage is poor (Michelsen 1975). 


\section{Environmental conditions}

The environmental conditions during the Early Jurassic in the Danish Subbasin have been discussed previously on the basis of ostracod faunas (Michelsen 1975). Based on thorough studies of the macrofossils, especially the bivalves, Pedersen (1986) discussed in detail the influence of physical and chemical parameters. New analyses of the organic content and composition of the strata were summarized by Thomsen et al. (1987), in a discussion of the oil and gas source rock potential of the Fjerritslev Formation. These data, which are compiled from six wells and presented member by member, have been made available to the author. Organic geochemical data from the Hyllebjerg-1 and Kvols-1 wells are presented in figs. 9 and 10 together with the gamma ray and sonic velocity logs. Analyses of the total organic carbon (TOC) content and the hydrogen index $(\mathrm{HI})$ are valuable for an evaluation of the environmental conditions, since they give an indication of bottom water conditions with respect to preservation of organic matter and of production of marine algae. A preliminary interpretation is given below and integrated with the environmental interpretations based on calcareous fossils by Pedersen (1986). All these data are compiled in fig. 11 and correlated to the sea-level curve of Hallam (1981).

\section{Organic geochemistry}

The TOC-values are constant throughout the Lower Jurassic succession in the Hyllebjerg-1 well, except for a slight increase in the upper part of the F-III member and in the F-IV member, corresponding to the Toarcian stage (fig. 9). This uniformity is a general trend in the well sections studied, although in the Hobro-1 and Rønde- 1 sections, a slight increase in TOC-value occurs in the lower part of the F-III member, corresponding to the Upper Pliensbachian. Two anomalies are present, however: a significant increase is seen in the uppermost F-III member (Toarcian) in the Kvols section (fig. 10), and in the F-IV member of the Rønde section. Thus the TOC-values indicate that conditions favouring preservation of the organic matter prevailed during Toarcian times.

The HI-values are low in the Hettangian and Sinemurian (F-Ia and F-Ib members). A small, but significant increase occurs in the lowermost Pliensbachian, below the boundary between F-Ib and F-II members (figs. 9 and 11). At the Pliensbachian-Toarcian bound- ary, between strata boundaries $\mathbf{k}$ and 1 , another significant increase of the HI-values is recorded (figs. 9 and 11). It is a general feature of the sections studied, that this latter increase in HI-values is first observed in strata of latest Pliensbachian age. It should be remembered that the analyses were carried out on cuttings samples which may result in an apparently gradual shift of geochemical characteristics. Two notable HI-anomalies occur in the Toarcian of the Kvols section (in the uppermost F-III member; fig. 10) and of the Rønde section (F-IV member), i.e. at the same stratigraphic levels as the anomalous TOC-values. In the Hyllebjerg section minor anomalous $\mathrm{HI}$-values are recorded from the upper part of the F-III member and from the F-IV member, corresponding to the Toarcian stage (fig. 9).

The variation in the HI-values suggests that there was a decrease in influx of terrestrial plant material or, alternatively, an increase in the production of marine algae at the transition from the Sinemurian to the Pliensbachian and from the Pliensbachian to the Toarcian. Decreased levels of oxygen within the bottom waters may have caused increased preservation of organic matter in latest Pliensbachian and in the Toarcian, as is indicated by the TOC-values.

Thomsen et al. (1987) suggested that the anomalous TOC and HI values are the result of sedimentation in rim-synclines, in which local anoxia was developed. However, the Kvols-1 well was drilled on a minor salt pillow and the Rønde-1 well is located on the eastern flank of the Voldum structure, i.e. outside the rimsyncline. In the Kvols section the geochemical anomaly occurs in the upper and probably condensed part of the F-III member, above strata boundary $\mathrm{m}$. A reduced influx of clastic material and a constant production of organic matter may explain the anomaly in this well. The anomaly present in the F-IV member in Rønde-1 may be related to a local topographic feature of the basin. Further investigations, both of these wells and other wells from the Danish Subbasin, are necessary for a conclusive interpretation of these local organic geochemical anomalies.

\section{Benthonic faunas}

The changing environmental conditions during deposition of the Fjerritslev Formation are reflected in the benthonic faunas (Michelsen 1975, Pedersen 1986) and 
can be correlated with the eustatic sea-level curve presented by Hallam (1981).

With the rising sea-level early in the Hettangian, sedimentation of clay was initiated in the central zone of the Danish Subbasin.

Sediments with a normal shale-facies fauna (sensu Morris 1979) were deposited during Hettangian, Early Sinemurian, and earliest Late Sinemurian times (Pedersen 1986). The diversity and density of the ostracod fauna increased during the Hettangian and earliest Early Sinemurian sea-level stillstand. A significant decrease in faunal diversity and density is recognized at the transition from the $O$. aspinata Zone to the $C$. betzi - C. crassireticulata Zone (fig. 11). This decrease is assumed to have occurred during late Early Sinemurian times (Michelsen 1975), and thus is correlatable with the important sea-level rise at this time (Hallam 1981). Contemporaneously, the Fjerritslev Formation overstepped the Gassum Formation in the Vedsted region (Michelsen 1978).

The diversity and density of the ostracod fauna increased during the early part of Late Sinemurian, which is contemporary with a sea-level stillstand (Hallam 1981). From the mid Sinemurian until the basal Lower Pliensbachian, the faunal density and diversity decrease (fig. 11). According to Pedersen (1986), the upper Upper Sinemurian and Pliensbachian sediments have a restricted shale-facies fauna, and the Late Sinemurian sea-level stillstand may explain the disappearance of the infaunal suspension feeding bivalves at this level.

The increases in both the diversity and density of the ostracod faunas in the Lower Pliensbachian interval and in $\mathrm{HI}$ values correlate with with a high sea-level stillstand (fig. 11). Near the northern margin of the basin, in the Frederikshavn region, the Fjerritslev Formation overstepped the Gassum Formation during the latest Sinemurian.

At the Lower-Upper Pliensbachian boundary, the diversity and density of the ostracod fauna decreases, but a renewed increase in these values is recorded from Upper Pliensbachian strata, coinciding with a high sealevel stillstand (Hallam 1981).

The absence of ostracods and the significant increase of TOC- and HI-values in the Toarcian succession indicate increased anoxia, probably resulting from basin deepening related to the Toarcian sea-level rise described by Hallam (1981). Within the F-IV member in the Haldager-1 and Vedsted-1 wells a rich monospecific ostracod fauna is found (Michelsen 1975), indicating a high stress environment (Hallam 1981). 


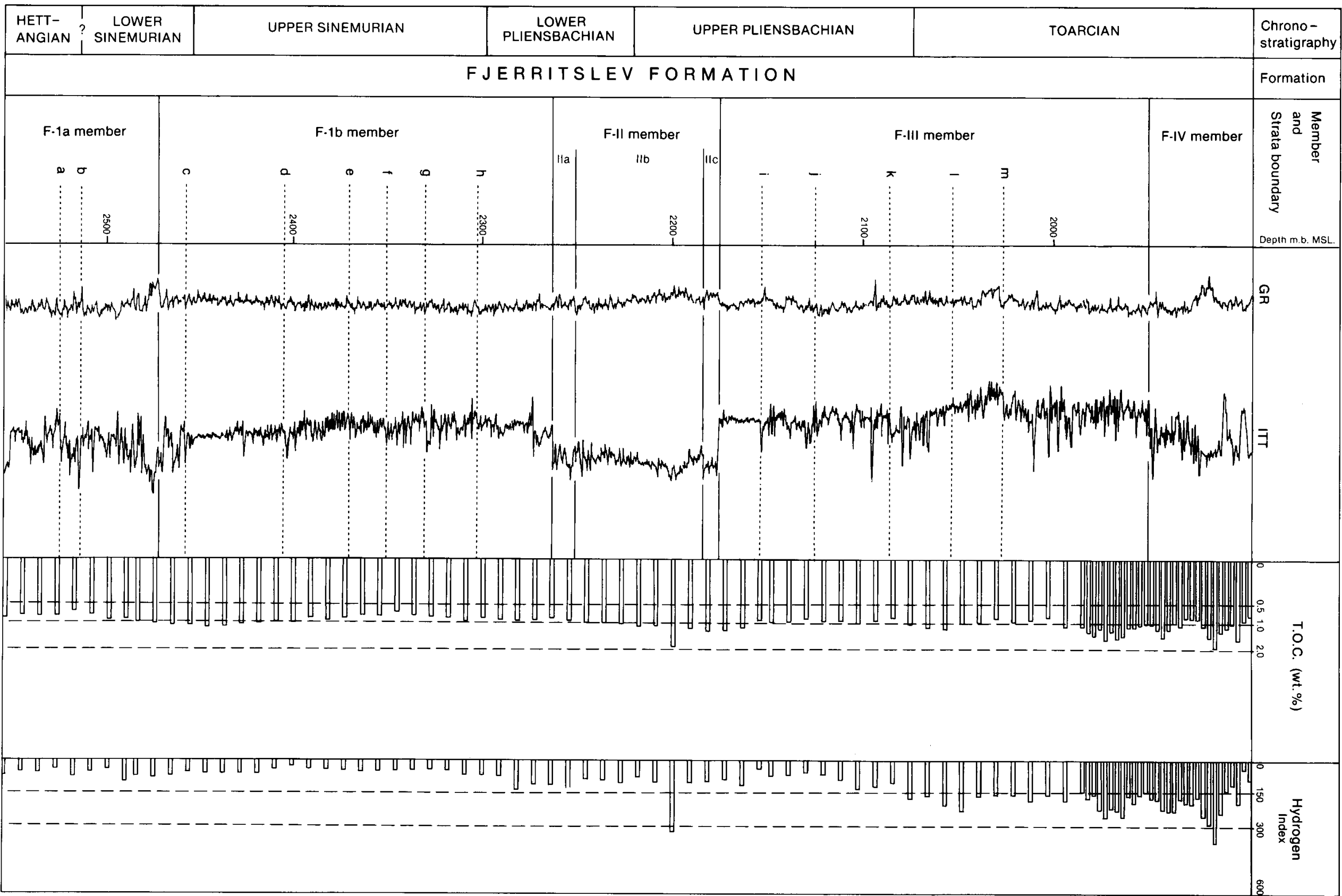




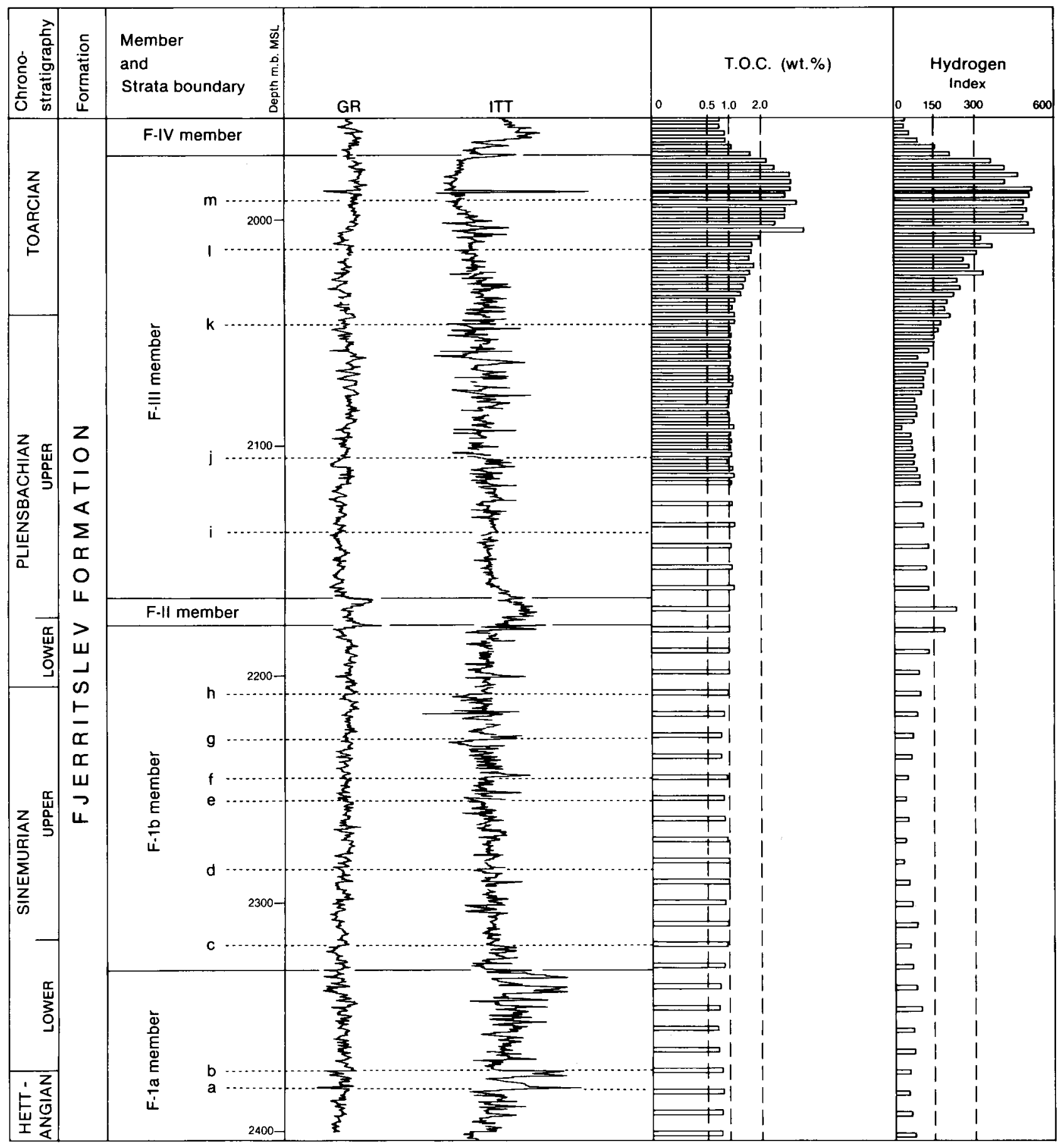

Fig. 10: Organic geochemistry of the Fjerritslev Formation in the Kvols-1 well, in relation to stratigraphic subdivision of the formation.

Fig. 9: Organic geochemistry of the Fjerritslev Formation in the Hyllebjerg-1 well, in relation to stratigraphic subdivision of the formation. 


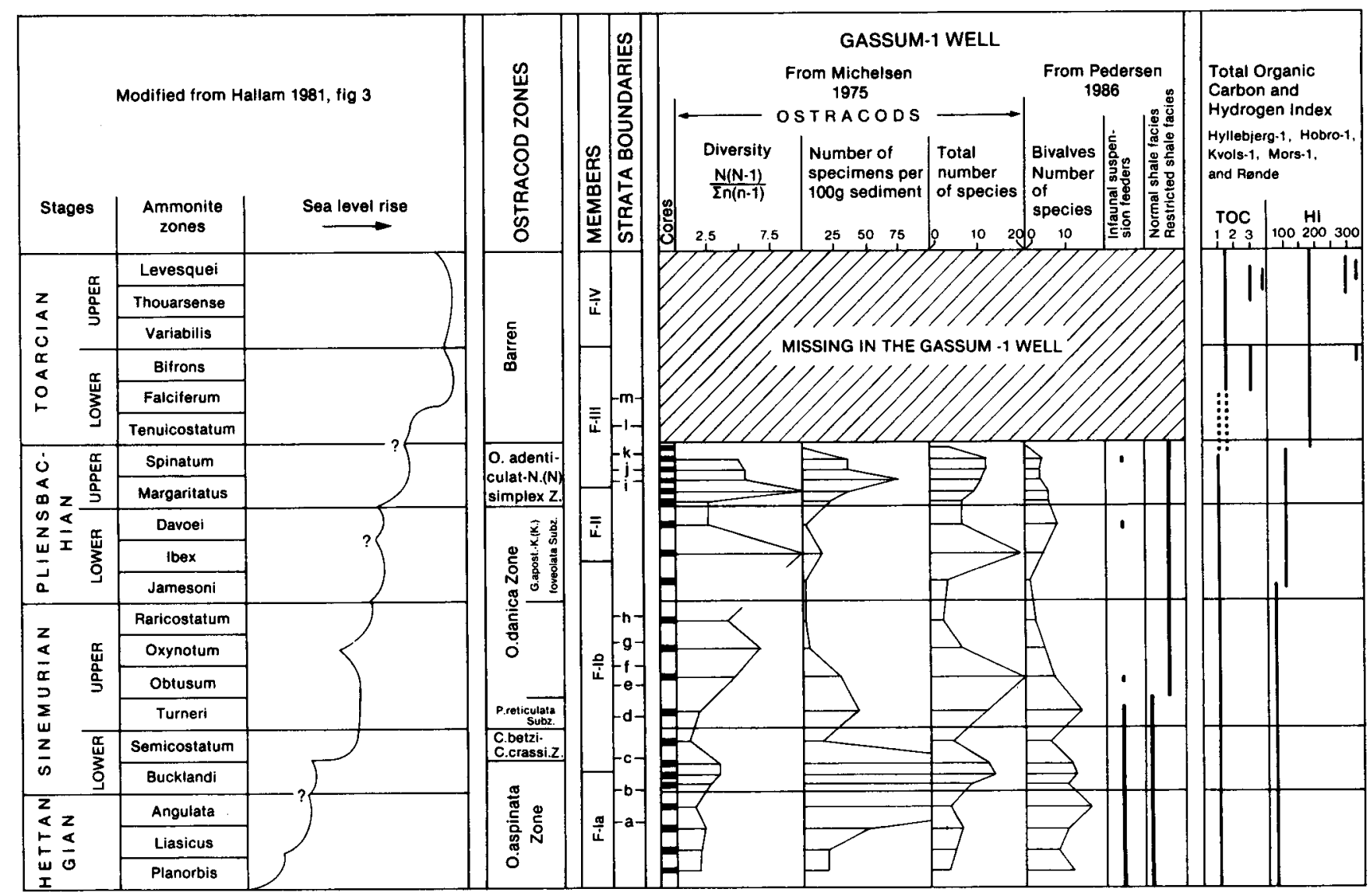

Fig. 11: The diversity and density of benthonic faunas and the organic geochemistry (Total Organic Contents and Hydrogen Index) of the Fjerritslev Formation plotted in relation to the sea-level curve of Hallam (1981, fig. 2). Note that the palaeontological data are from core samples from the Gassum-1 well, where the ostracod zones are defined and correlated with the standard ammonite zonation. The organic geochemical data are from well sections represented by cuttings samples. The chronostratigraphic subdivision of these well sections is based on the integration of the ostracod biostratigraphy with the log-sequence stratigraphy.

\section{Summary}

The integration of faunal data with organic geochemistry leads to the conclusion that the environmental conditions within the central portion of the Danish Subbasin were primarily controlled by the eustatic sealevel.

The five major phases of eustatic sea-level rise described by Hallam (1981) appear to be reflected in changes of the benthonic faunas. The diversity and density of the ostracod fauna were low during the initial phase of the sea-level rise, probably due to decreased oxygen content of the bottom water caused by increased water depth. The faunal diversity and density increased during the higher stillstand of the sea-level. The five phases of sea level rise occurred at the beginning of the Hettangian, the mid Early Sinemurian, the mid to late of Late Sinemurian, the latest Early Pliensbachian, and the beginning of the Toarcian. The latter stage is characterized by a sequence barren of ostracods.
The five phases of sea-level rise cannot be correlated with the lithostratigraphic boundaries, with the exception of the first phase which, in the central part of the basin, coincides with the base of the Fjerritslev Formation. The second phase can be correlated with the strata boundary $c$, the third with the middle of the F-Ib member, and the fourth with the upper part of the F-II member. The beginning of the last phase of sea-level rise is correlated with the log-sequence between the strata boundaries $\mathbf{k}$ and 1 .

During the overall Early Jurassic transgression the oxygen levels within the bottom water decreased, probably due to increasing water depth. Early in the Late Sinemurian, the infaunal suspension-feeding bivalves disappeared, and restricted shale-facies dominated during the Late Sinemurian and Pliensbachian (Pedersen 1986). At the end of the Pliensbachian the benthonic faunas disappeared due to increasing anoxia, as indicated by the organic geochemical analyses. 


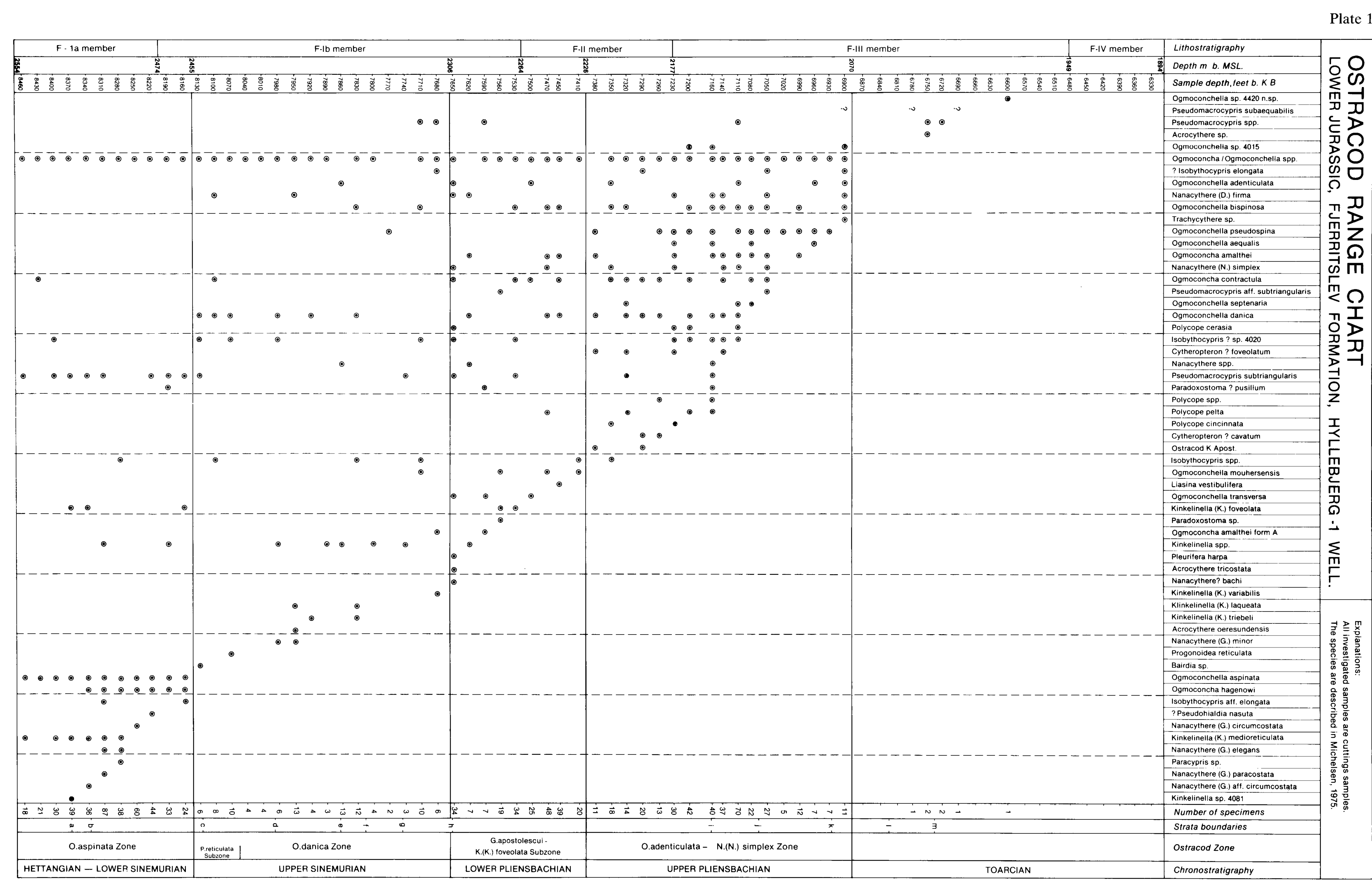

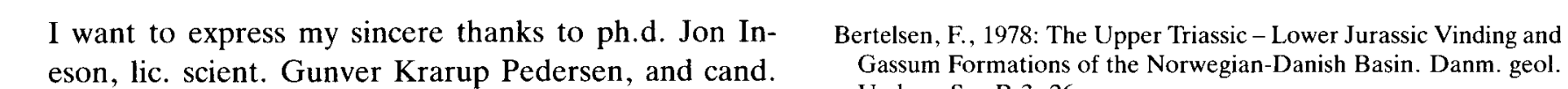

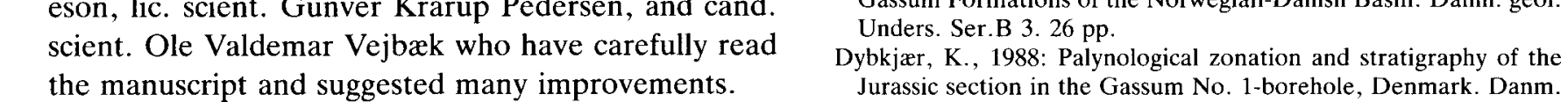

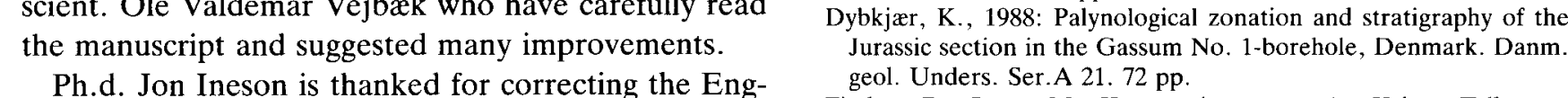

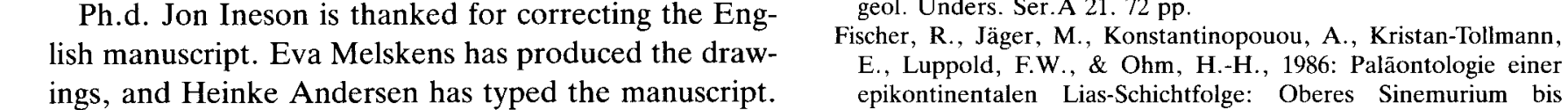

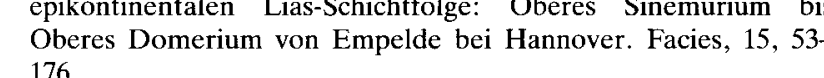

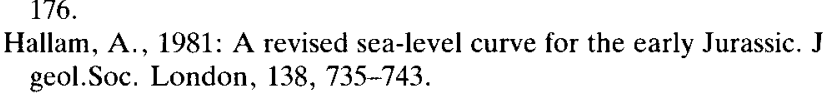

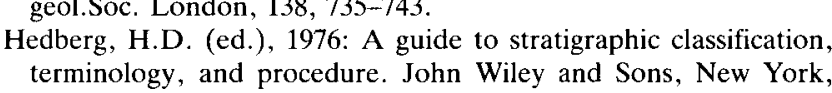

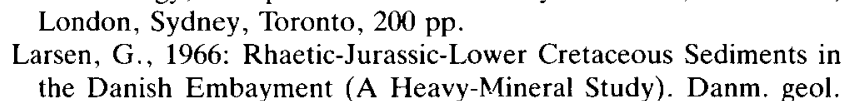

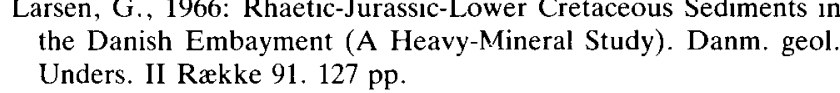

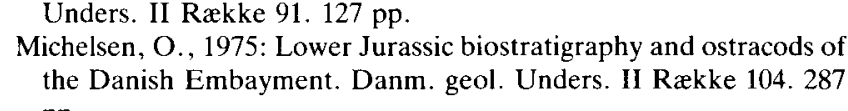

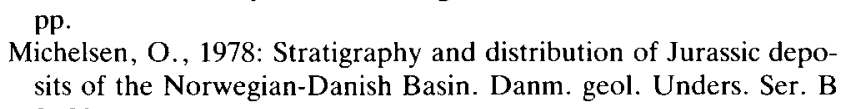

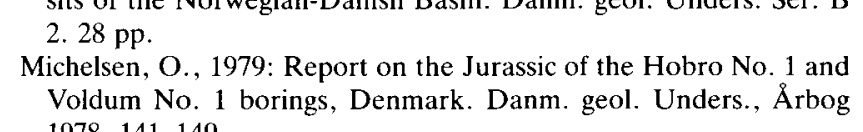

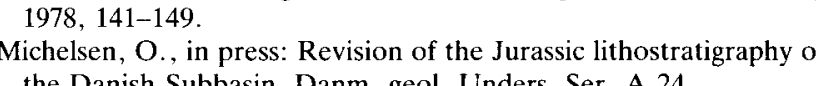

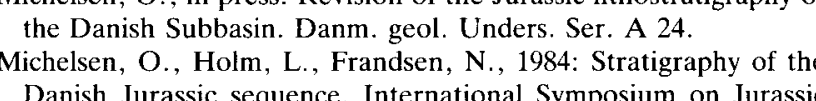

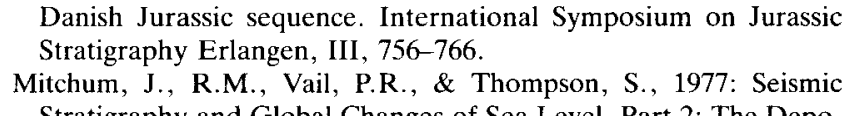

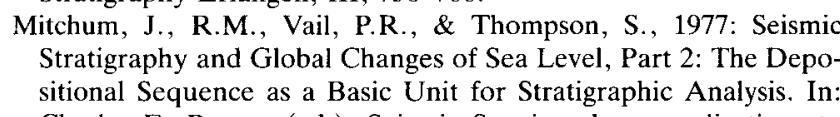

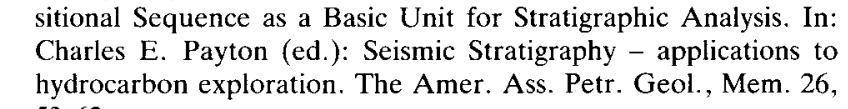

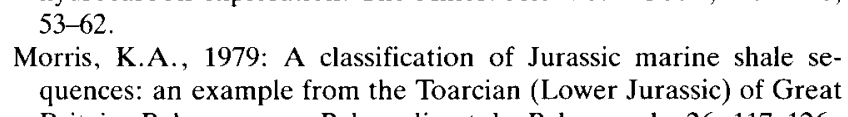

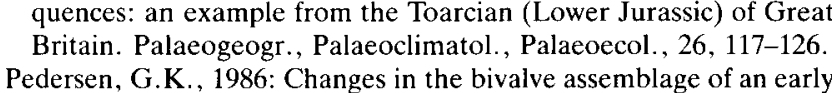

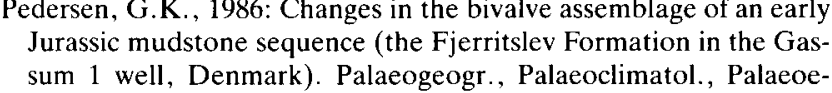

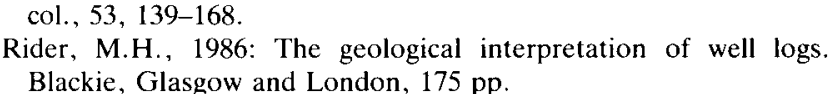

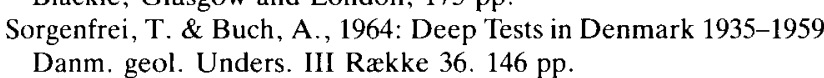

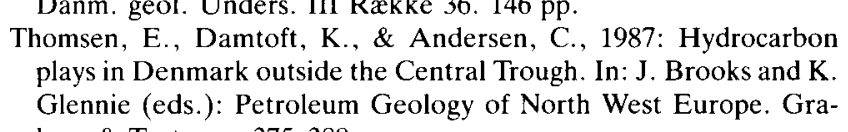

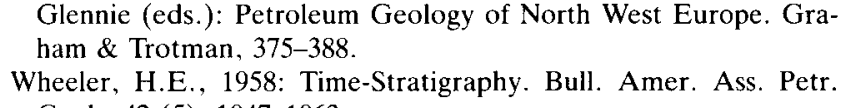


The lithostratigraphic, biostratigraphic, and chronostratigraphic subdivisions of the Lower Jurassic Fjerritslev Formation are discussed in relation to a newly established log-sequence stratigraphy, which is demonstrated being of chronostratigraphic significance.

The depositional environment is discussed on the basis of previously published data on the benthonic faunas and few organic geochemical data. 